\title{
Cultura y Universidades
}

\author{
Hugo ENRIQue SÁEz
}

Director de Universidades

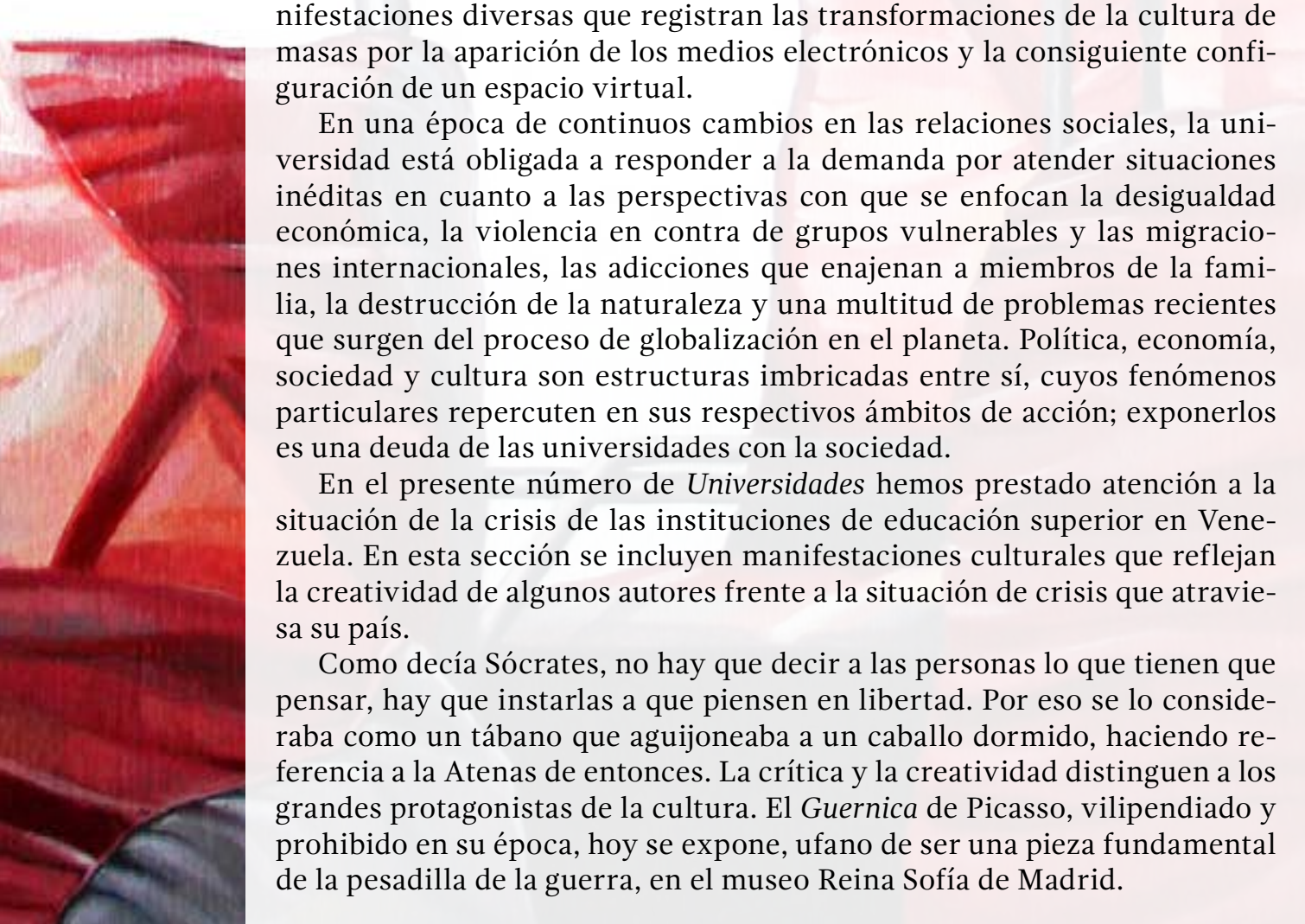

Las modernas universidades se han construido librando una lucha permanente por la autonomía, dado que sus principales funciones (investigación y docencia) requieren un espacio de libertad para indagar nuevos territorios del conocimiento. A estas funciones se suma un compromiso con el desarrollo y la divulgación de la cultura.

A partir de este número, la revista Universidades inaugura una sección, Reflejos, dedicada a la cultura en un sentido amplio. Tendrán cabida manifestaciones diversas que registran las transformaciones de la cultura de masas por la aparición de los medios electrónicos y la consiguiente configuración de un espacio virtual.

En una época de continuos cambios en las relaciones sociales, la universidad está obligada a responder a la demanda por atender situaciones inéditas en cuanto a las perspectivas con que se enfocan la desigualdad económica, la violencia en contra de grupos vulnerables y las migraciones internacionales, las adicciones que enajenan a miembros de la familia, la destrucción de la naturaleza y una multitud de problemas recientes que surgen del proceso de globalización en el planeta. Política, economía, sociedad y cultura son estructuras imbricadas entre sí, cuyos fenómenos particulares repercuten en sus respectivos ámbitos de acción; exponerlos es una deuda de las universidades con la sociedad.

En el presente número de Universidades hemos prestado atención a la situación de la crisis de las instituciones de educación superior en Venezuela. En esta sección se incluyen manifestaciones culturales que reflejan la creatividad de algunos autores frente a la situación de crisis que atraviesa su país.

Como decía Sócrates, no hay que decir a las personas lo que tienen que pensar, hay que instarlas a que piensen en libertad. Por eso se lo consideraba como un tábano que aguijoneaba a un caballo dormido, haciendo referencia a la Atenas de entonces. La crítica y la creatividad distinguen a los grandes protagonistas de la cultura. El Guernica de Picasso, vilipendiado y prohibido en su época, hoy se expone, ufano de ser una pieza fundamental de la pesadilla de la guerra, en el museo Reina Sofía de Madrid. 